\title{
Assessment of Sexuality and Frailty in Older Adults Living in Northeast Brazil*
}

* This study was carried out with the support of the Coordination for the Improvement of Higher Education Personnel, Brazil, funding code 001.

凶Edison Vitório de Souza-Júnior

https://orcid.org/0000-0003-0457-0513 Universidade de São Paulo, Brasil. edison.vitorio@usp.br

Gabriele da Silva Santos

https://orcid.org/o0oo-0001-6969-0271 Universidade Federal da Bahia, Brasil. novaes.gabriiele@ufba.br

Suziane de Aguiar Brito

https://orcid.org/0000-0003-3004-5843 Universidade de São Paulo, Brasil. suzianeaguiar6@usp.br

Sterline Therrier

https://orcid.org/0000-0002-7713-3288 Universidade Federal de Alfenas, Brasil. ppgenf@unifal-mg.edu.br

\section{Lais Reis Siqueira}

https://orcid.org/0000-0002-6720-7642 Universidade Federal de Alfenas, Brasil. ppgenf@unifal-mg.edu.br

Namie Okino Sawada

https://orcid.org/0000-0002-1874-3481 Universidade Federal de Alfenas, Brasil. namie.sawada@unifal-mg.edu.br

Received: 10/25/2020

Sent to reviewers: $12 / 01 / 2020$ Approved by reviewers: 07/22/2021 Accepted: 09/27/2021

\section{DOI: 10.5294/aqui.2022.22.1.8}

To cite this article / Para citar este artículo / Para citar este artigo

Souza-Junior EV, Santos GS, Brito SA, Therrier S, Siqueira LR, Sawada NO. Assessment of sexuality and frailty in older adults living in Northeast Brazil. Aquichan. 2022;22(1):e2218. DOI: https://doi.org/10.5294/aqui.2022.22.1.8 
Theme: promotion and prevention.

Contributions to the subject: this study contributes as an instigation for the possibility of identifying new non-pharmacological approaches for the promotion and protection of the health of older adults. In this case, the healthy experiences of sexuality can constitute one of these approaches and, in some way, contribute to the maintenance of health, as this study found positive and negative correlations between the experiences of sexuality and frailty in older adults. 


\section{Abstract}

Objective: to evaluate the experiences of sexuality and its correlation with frailty among older adults. Materials and methods: cross-sectional study carried out with a total of 250 older adults living in the Northeast of Brazil. They answered three instruments to obtain biosociodemographic, sexuality and frailty data. The analysis was performed using Spearman correlation, Mann-Whitney and Kruskal-Wallis test with $95 \%$ confidence interval. Results: sexual intercourse was negatively correlated with reduced strength $(\rho=-0.263 ; p<0.001)$ and walking speed $(\rho=-0.201 ; p=0.001)$ and positively correlated with reported fatigue ( $\rho=0.149 ; p=0.018)$. Affective relationships were negatively correlated with reduced strength $(\rho=-0.254 ; p<0.001)$ and walking speed $(\rho=-0.207 ; p=0.001)$ and positively correlated with reported fatigue $(\rho=0.207 ; p=0.001)$. Finally, physical and social adversities were positively correlated with reduced strength $(\rho=0.279 ; p<0.001)$, reduced walking speed $(\rho=0.261 ; p<0.001)$ and low physical activity ( $\rho=0.140 ; p=0.034)$, in addition to being negatively correlated with reported fatigue $(\rho=-0.171 ; p=0.009)$. Conclusion: it was found that the sexuality of older adults is better experienced in affective relationships and weak positive and negative correlations between sexuality and frailty.

\section{Keywords (Source: DeCS)}

Public health; older adults health; sexuality; Frailty; comprehensive health care. 


\section{Evaluación de la sexualidad y la fragilidad en ancianos habitantes del noreste de Brasil}

* El trabajo se realizó con el apoyo de la Coordenação de Aperfeiçoamento de Pessoal de Nível Superior, Brasil, código de financiación o01.

\section{Resumen}

Objetivo: evaluar las vivencias de la sexualidad y su correlación con la fragilidad entre ancianos. Materiales y métodos: estudio seccional realizado con 250 ancianos habitantes en el noreste de Brasil. Los ancianos contestaron tres instrumentos para obtener datos biosociodemográfico, la sexualidad y la fragilidad. Se realizó el análisis con base en la correlación de Spearman, prueba de Mann-Whitney y Kruskal-Wallis con intervalo de confianza del $95 \%$. Resultados: el acto sexual se correlacionó negativamente con la reducción de la fuerza $(\rho=-0,263 ; p<0,001)$ y de la velocidad de marcha $(\rho=-0,201$; $p=0,001)$ y positivamente a la fadiga relatada $(\rho=0,149 ; p=0,018)$. Las relaciones afectivas se correlacionaron negativamente a la reducción de la fuerza $(\rho=-0,254 ; p<0,001)$ y de la velocidad de marcha $(\rho=-0,207 ; p=0,001)$ y positivamente a la fadiga relatada $(\rho=0,207 ; p=0,001)$. Por fin, las adversidades física y social se correlacionaron positivamente a la reducción de la fuerza $(\rho=0,279 ; p<$ $0,001)$, a la reducción de la velocidad de marcha $(\rho=0,261 ; p<0,001)$ y a la baja actividad física ( $\rho=0,140 ; p=0,034)$, además de correlacionar negativamente con la fadiga relatada $(\rho=-0,171 ; p=0,009)$. Conclusiones: se encontró que la sexualidad de los ancianos se vivencia de mejor manera en las relaciones afectivas y correlaciones positivas y negativas de magnitud débil entre la sexualidad y la fragilidad.

\section{Palabras clave (Fuente: DeCS)}

Salud pública; salud del anciano; sexualidad; fragilidad; atención integral de salud. 


\section{Avaliação da sexualidade e da fragilidade em idosos residentes no Nordeste do Brasil}

* O presente trabalho foi realizado com apoio da Coordenação de Aperfeiçoamento de Pessoal de Nível Superior, Brasil, código de financiamento 001.

\section{Resumo}

Objetivo: avaliar as vivências da sexualidade e sua correlação com a fragilidade entre idosos. Materiais e métodos: estudo seccional realizado com 250 idosos residentes no Nordeste do Brasil. Os idosos responderam a três instrumentos para a obtenção dos dados biossociodemográfico, da sexualidade e da fragilidade. A análise foi realizada com a correlação de Spearman, teste de Mann-Whitney e Kruskal-Wallis com intervalo de confiança de $95 \%$. Resultados: o ato sexual se correlacionou negativamente à redução da força $(\rho=-0,263 ; p<0,001)$ e da velocidade de caminhada $(\rho=-0,201$; $p=0,001)$ e positivamente à fadiga relatada $(\rho=0,149 ; p=0,018)$. As relações afetivas se correlacionaram negativamente à redução da força $(\rho=-0,254 ; p<0,001)$ e da velocidade de caminhada $(\rho=$ $-0,207 ; p=0,001)$ e positivamente à fadiga relatada $(\rho=0,207 ; p=$ $0,001)$. Por fim, as adversidades física e social se correlacionaram positivamente à redução da força $(\rho=0,279 ; p<0,001)$, à redução da velocidade de caminhada $(\rho=0,261 ; p<0,001)$ e à baixa atividade física ( $\rho=0,140 ; p=0,034$ ), além de se correlacionar negativamente com a fadiga relatada $(\rho=-0,171 ; p=0,009)$. Conclusões: constatou-se que a sexualidade dos idosos é vivenciada de melhor forma nas relações afetivas e correlações positivas e negativas de fraca magnitude entre a sexualidade e a fragilidade.

\section{Palavras-chave (Fonte: DeCS)}

Saúde pública; saúde do idoso; sexualidade; fragilidade; assistência integral à saúde. 
Sexuality is an essential component of the individual's identity and influences both sexual expressions and the completeness of human functioning. It can be said that sexuality has two aspects: procreative, recreational or pleasurable. The procreative aspect is associated with the idea of reproduction and represents a very small part of sexuality, while the recreational or pleasurable aspect (pleasure and hedonism) is a more complex component and involves intimacy and the sexual act as a social connection (1).

Thus, the expression of sexuality includes thoughts, beliefs, values, attitudes, eroticism, fantasies, desires, practices, roles (1), partnership, functions, motivation (2), including sexual behaviors (1). It should be remembered that sexuality is present throughout the life cycle, regardless of age group, gender, sexual orientation or any other clinical and social stratification. It is a complex area that is strongly influenced by the cultural context in which the individual is inserted (3).

It is estimated that around $8.5 \%$ of the world's population is aged 65 or over, with the prospect of an increase to $16.7 \%$ in 2050 (4). The aging process is often accompanied by chronic diseases and cognitive alterations that evolve with unsatisfactory outcomes over the years (5). In addition, it is estimated that around 10 to $25 \%$ of the older adults population has certain clinical conditions that predispose them to a greater risk of frailty with consequent financial impacts on the government and family system (6).

Frailty can be defined as a biological syndrome that reduces reserve and resistance to stressors (5) and has a high prevalence in old age, characterized as being one of the factors responsible for the high rates of adverse health outcomes, such as morbidity and mortality, falls and institutionalization (7). From this perspective, frailty can be relevant for risk prediction and decision-making in health services (5).

However, although the prevalence of frailty increases substantially with age, especially in people over 80 years old, it should be remembered that the accuracy of the prevalence rates depends on the definition adopted, as there are different approaches regarding specific aspects of Frailty (8).

Thus, this study will adopt the frailty framework proposed by Fried (7), who defined it as a clinical syndrome with the presence of at least three or more of the following criteria: unintentional weight loss, self-reported exhaustion, weakness, reduced walking speed and low physical activity (7).

Thus, the relevance of this study involves the possibility of identifying new non-pharmacological approaches for promoting and protecting the health of older adults. In this case, the healthy experiences of sexuality can constitute one of these approaches, and somehow contribute to the maintenance of health, which can be explored in future research, especially based on the salutogenesis model (9). 
This model was devised by Israeli sociologist Aaron Antonovsky with the purpose of understanding the development of health, considering a continuous state of health and disease, going deeper into its maintenance and use of available resources so that the entire process becomes effective. In this model, it is assumed that, if individuals became active beings in decision-making that culminate in health-promoting behaviors, the risks and suffering would be mitigated $(9,10)$.

From this perspective, this study raises the hypothesis that sexuality is negatively correlated with frailty among older adults. It should be remembered that its expression continues to constitute an integral element of quality of life in old age and its valuation in the care context is essential for the provision of health care and the planning of institutional services. Thus, an expanded and holistic understanding of sexuality among older adults can provide subsidies that increase the quality of research, education, policies and, especially, care for this population (2).

Nevertheless, it is noteworthy that most investigations that address sexuality in old age focus on the medical model of sexuality and on the physiological impact of aging on the sexual response of men and women (2), contributing with few reflections on the relationship between sexuality itself with health conditions in old age. Thus, the objective was to evaluate the experiences of sexuality and its correlation with frailty among older adults.

\section{Materials and methods}

This is a cross-sectional study with a descriptive and analytical approach, carried out with a total of 250 older adults living in the Northeast of Brazil. The older adults were recruited using the consecutive non-probabilistic technique through the dissemination of the survey on the Facebook social network. The authors created a page exclusively for the development of the research, in which a personalized invitation was published with the indication of the link institution, the responsible researchers, the inclusion criteria of the participants and the contact number for the clarification of doubts and/or suggestions. In addition, along with the invitation, a hyperlink was published, prepared with the Google Forms tool, which gave direct access to the survey questionnaire.

For the construction of the questionnaire, instruments validated and standardized for the Brazilian population were used. The questionnaire was structured in three parts: biosociodemographic, sexuality and frailty. It is noteworthy that, before the older adults access the content of the questionnaire, it was mandatory to include their respective valid e-mails, in order to ensure the quality of the data through the identification of possible multiple responses by the same participant. In addition, the e-mail served as a strategy to send the second copy of the informed consent form and as a space for exchanging information about the relevance of the research to society. 
The biosociodemographic survey aimed to describe the profile of older adults through information such as age group (from 60 years old), biological sex (male and female), education, religious belief, ethnicity, marital status, time living with the partner, sexual orientation and if they had any orientation about sexuality by health professionals.

The "sexuality" survey was assessed using the Affective and Sexual Experiences of Older Adults Scale (11). This is a psychometric scale composed of constructs that assess sexuality in its expanded understanding, considering the sexual aspects (dimension "sexual act"), affective (domain "affective relationships") and physical-social (domain "physical and social adversities"). It consists of 38 items with five possibilities for objective answers and organized in a Likert-type scale, in which: 1 = never; 2 = rarely; 3 = sometimes; 4 = often and $5=$ always. This instrument does not have a cutoff point, with the lowest/highest scores corresponding, respectively, to the worst/better experience of sexuality for the dimensions "sexual act" and "affective relationships". The dimension "physical and social adversity" has negative issues and, therefore, its interpretation is opposite to the other two dimensions, and the lower/higher the score, respectively, the better/worse is the older adult's coping with the adversities that hinder their experiences in sexuality (11).

Finally, the "Frailty" survey was constructed with the Self-Reported Frailty Instrument (12). It is composed of six questions that assess the five components of the frailty phenotype proposed by Fried (7): unintentional weight loss, reduced strength, reduced walking speed, low physical activity and reported fatigue. The "weight loss" component was scored in older adults who reported a loss of more than three kilograms in the last 12 months; the components "reduced strength", "walking speed" and "low physical activity" were scored in the positive responses in relation to the last 12 months in the dichotomous options (yes or no); finally, the component "reported fatigue" was scored in older adults who mentioned the option "sometimes" or "most of the time" in at least one of the questions in relation to the last week. The final classification was: non-frail (older adults who did not score any item), pre-frail (older adults who scored positively between one and two items) and frail (those who scored from three items) (12).

To participate in the study, the older adults met the following inclusion criteria: having active Facebook account and internet access; being 60 years old or older; living in the Northeast region, of both sexes and who were married, in a stable union or with a steady partner. Older adults living in long-term care facilities and hospitalized ones were excluded. Due to the need for skills in handling electronic devices that provide access to the internet, in addition to active interaction in social networks, the instrument to assess the cognition of older adults was not applied.

To delimit the study scenario, the authors used the geolocation tool available on the page created, which only allowed the inclusion of old- 
er adults living in the Northeast of Brazil. Nevertheless, the authors resorted to the post boosting tool, which Facebook extended the dissemination of questionnaires to as many people as possible until reaching the intended sample within the pre-established scenario.

The sample size was defined a priori considering an infinite population, prevalence of frailty in older adults of $16.6 \%, \alpha=0.05(5 \%)$ and confidence interval $(\mathrm{Cl})=95 \%(\mathrm{z} \alpha / 2=1.96)$, which resulted in a minimum sample of 213 older adults (13). However, more than $15 \%$ was added to the calculation to compensate for possible losses due to duplication and/or incompleteness of responses, resulting in 250 participants in the final sample.

Data were stored and analyzed using the IBM SPSS ${ }^{\circledR}$ statistical software. Initially, data distribution was verified using the Kolmogorov-Smirnov test, showing non-normal distributions $(p<0.05)$. Thus, non-parametric statistics were used for the analyses, using the Mann-Whitney test for variables with up to two categories and Kruskal-Wallis for variables with three or more categories, with subsequent application of the Bonferroni post-hoc test when needed. The analysis of the independent (sexuality) and the dependent (frailty) variable was performed using Spearman's correlation ( $\rho)$. The correlation coefficients were interpreted as follows: weak magnitude $(\rho<0.4)$; moderate magnitude (from $\rho \geq 0.4$ to $<0.5$ ) and strong magnitude $(\rho \geq 0.5)(14)$. A $95 \% \mathrm{Cl}(p<0.05)$ was adopted for all statistical analyses.

Categorical variables were presented as absolute and relative frequencies. As for the quantitative variables, through the median $\left(M_{d}\right)$, interquartile range (IQ) and middle ranks (MR).

This study fulfilled the ethical requirements for the development of research with human beings, according to Resolution 466/2012 of the National Health Council. Furthermore, it was approved by the Research Ethics Committee of the University of Sao Paulo at Ribeirao Preto Nursing School, under Opinion 4319644 and Certificate of Presentation for Ethical Appreciation 32004820000005393.

\section{Results}

Table 1 shows the distribution of the participants' responses in the sexuality scale and its three dimensions.

Table 1. Absolute and relative frequencies of the Affective and Sexual Experiences Scale of Older adults

\begin{tabular}{|c|c|c|c|c|c|c|c|c|c|c|}
\hline & \multicolumn{2}{|c|}{ Never } & \multicolumn{2}{|c|}{ Rarely } & \multicolumn{2}{|c|}{ Sometimes } & \multicolumn{2}{|c|}{ Frequently } & \multicolumn{2}{|c|}{ Always } \\
\hline & $\mathbf{n}$ & $\%$ & n & $\%$ & $\mathbf{n}$ & $\%$ & $\mathbf{n}$ & $\%$ & n & $\%$ \\
\hline 1. I have a favorable attitude towards sexuality in old age. & 16 & 6.4 & 20 & 8.0 & 55 & 22.0 & 67 & 26.8 & 92 & 36.8 \\
\hline 4. I desire my partner. & 6 & 2.4 & 13 & 5.2 & 46 & 18.4 & 76 & 30.4 & 109 & 43.6 \\
\hline 5. My partner and I have sex. & 13 & 5.2 & 30 & 12.0 & 55 & 22.0 & 94 & 37.6 & 58 & 23.2 \\
\hline 9. Sexual experiences are good for my self-esteem. & 3 & 1.2 & 11 & 4.4 & 23 & 9.2 & 30 & 12.0 & 183 & 73.2 \\
\hline 10. Enjoying my sexuality means being alive. & 6 & 2.4 & 9 & 3.6 & 19 & 7.6 & 26 & 10.4 & 190 & 76.0 \\
\hline 11. I feel desired by my partner. & 12 & 4.8 & 21 & 8.4 & 59 & 23.6 & 58 & 23.2 & 100 & 40.0 \\
\hline
\end{tabular}




\begin{tabular}{|c|c|c|c|c|c|c|c|c|c|c|}
\hline & \multicolumn{2}{|c|}{ Never } & \multicolumn{2}{|c|}{ Rarely } & \multicolumn{2}{|c|}{ Sometimes } & \multicolumn{2}{|c|}{ Frequently } & \multicolumn{2}{|c|}{ Always } \\
\hline & $n$ & $\%$ & $\mathbf{n}$ & $\%$ & $\mathbf{n}$ & $\%$ & $n$ & $\%$ & $\mathbf{n}$ & $\%$ \\
\hline 14. I find that having sex improves our relationship. & 10 & 4.0 & 8 & 3.2 & 43 & 17.2 & 49 & 19.6 & 140 & 56.0 \\
\hline 20. Sexual experiences make me feel more alive. & 6 & 2.4 & 7 & 2.8 & 26 & 10.4 & 29 & 11.6 & 182 & 72.8 \\
\hline 22. I see the existence of desire in our relationship. & 14 & 5.6 & 24 & 9.6 & 45 & 18.0 & 53 & 21.2 & 114 & 45.6 \\
\hline 24. I believe that, in old age, I remain a beautiful person. & 8 & 3.2 & 15 & 6.0 & 65 & 26.0 & 52 & 20.8 & 110 & 44.0 \\
\hline 26. I feel good when we have sex. & 8 & 3.2 & 10 & 4.0 & 35 & 14.0 & 34 & 13.6 & 163 & 65.2 \\
\hline 28. Our sexual experiences are pleasurable. & 12 & 4.8 & 20 & 8.0 & 47 & 18.8 & 49 & 19.6 & 122 & 48.8 \\
\hline 29. I need the experiences of sexuality to live. & 21 & 8.4 & 17 & 6.8 & 49 & 19.6 & 56 & 22.4 & 107 & 42.8 \\
\hline 31. The practice of sexuality gives me well-being. & 6 & 2.4 & 6 & 2.4 & 32 & 12.8 & 41 & 16.4 & 165 & 66.0 \\
\hline $\begin{array}{l}\text { 34. I express my sexuality without caring what others think } \\
\text { of me. }\end{array}$ & 26 & 10.4 & 20 & 8.0 & 43 & 17.2 & 43 & 17.2 & 118 & 47.2 \\
\hline 35. My partner and I usually date. & 15 & 6.0 & 25 & 10.0 & 73 & 29.2 & 75 & 30.0 & 62 & 24.8 \\
\hline 36. With advancing age, I feel I have lost interest in sex. & 110 & 44.0 & 46 & 18.4 & 76 & 30.4 & 8 & 3.2 & 10 & 4.0 \\
\hline 38. Kisses and cuddles are part of our relationship routine. & 18 & 7.2 & 31 & 12.4 & 65 & 26.0 & 51 & 20.4 & 85 & 34.0 \\
\hline \multicolumn{11}{|l|}{\begin{tabular}{|l|} 
Dimension II - Affective relationships \\
\end{tabular}} \\
\hline 2. I enjoy being with my partner. & 6 & 2.4 & 14 & 5.6 & 28 & 11.2 & 62 & 24.8 & 140 & 56.0 \\
\hline 3. My partner enjoys privacy. & 5 & 2.0 & 12 & 4.8 & 34 & 13.6 & 60 & 24.0 & 139 & 55.6 \\
\hline 6. I feel that my partner likes me. & 9 & 3.6 & 14 & 5.6 & 46 & 18.4 & 70 & 28.0 & 111 & 44.4 \\
\hline 7. We are friends. & 4 & 1.6 & 4 & 1.6 & 19 & 7.6 & 43 & 17.2 & 180 & 72.0 \\
\hline 8. I love my partner. & 4 & 1.6 & 6 & 2.4 & 23 & 9.2 & 27 & 10.8 & 190 & 76.0 \\
\hline 12. Our relationship is filled with a lot of affection. & 13 & 5.2 & 23 & 9.2 & 58 & 23.2 & 57 & 22.8 & 99 & 39.6 \\
\hline 13. I accept the changes caused by aging. & 16 & 6.4 & 8 & 3.2 & 70 & 28.0 & 37 & 14.8 & 119 & 47.6 \\
\hline $\begin{array}{l}\text { 15. I'm not ashamed or afraid to express to my partner what } \\
\text { I feel. }\end{array}$ & 29 & 11.6 & 11 & 4.4 & 48 & 19.2 & 41 & 16.4 & 121 & 48.4 \\
\hline 16. I think sexuality in old age is normal. & - & 0.0 & 9 & 3.6 & 46 & 18.4 & 34 & 13.6 & 159 & 63.6 \\
\hline 17. I feel my partner enjoys being with me. & 8 & 3.2 & 18 & 7.2 & 38 & 15.2 & 44 & 17.6 & 142 & 56.8 \\
\hline 18. Our relationship is based on companionship. & 5 & 2.0 & 10 & 4.0 & 28 & 11.2 & 52 & 20.8 & 155 & 62.0 \\
\hline 19. I see the existence of love in our relationship. & 11 & 4.4 & 11 & 4.4 & 32 & 12.8 & 47 & 18.8 & 149 & 59.6 \\
\hline 21. I see complicity in our relationship. & 12 & 4.8 & 17 & 6.8 & 36 & 14.4 & 44 & 17.6 & 141 & 56.4 \\
\hline 23. I feel affection for my partner. & 5 & 2.0 & 12 & 4.8 & 30 & 12.0 & 43 & 17.2 & 160 & 64.0 \\
\hline 25. I feel loved by my partner. & 8 & 3.2 & 15 & 6.0 & 40 & 16.0 & 46 & 18.4 & 141 & 56.4 \\
\hline 27. I know I can count on my partner. & 9 & 3.6 & 11 & 4.4 & 35 & 14.0 & 34 & 13.6 & 161 & 64.4 \\
\hline $\begin{array}{l}\text { 33. Sexual experiences are important for the quality of life } \\
\text { of older adults. }\end{array}$ & 3 & 1.2 & 8 & 3.2 & 39 & 15.6 & 50 & 20.0 & 150 & 60.0 \\
\hline \multicolumn{11}{|l|}{ Dimension III - Physical and social adversity } \\
\hline 32. Some health problems hinder my sexual experiences. & 62 & 24.8 & 35 & 14.0 & 110 & 44.0 & 24 & 9.6 & - & 0.0 \\
\hline $\begin{array}{l}\text { 30. I feel uncomfortable with the changes in my sexuality } \\
\text { brought by aging. }\end{array}$ & 52 & 20.8 & 34 & 13.6 & 100 & 40.0 & 38 & 15.2 & 26 & 10.4 \\
\hline $\begin{array}{l}\text { 37. I'm afraid of being a victim of prejudice because of my } \\
\text { attitudes towards sexuality. }\end{array}$ & 151 & 60.4 & 26 & 10.4 & 58 & 23.2 & 6 & 2.4 & 9 & 3.6 \\
\hline
\end{tabular}

Source: Self elaboration from Vieira (11).

Table 2 shows the absolute and relative frequencies of the questions of the self-reported frailty instrument, according to its five components.

It is observed in Table 3 that non-frail and pre-frail older adults did not present a great discrepancy between their experiences of sexuality in the three dimensions. However, older adults classified as frail had the worst experiences in all dimensions of sexuality. The lowest medians observed among frail older adults in the sexual act and in affective relationships indicate that they experience these two dimensions with worse quality, when compared to non-frail and pre-frail older adults. The highest median in physical and social adversities indicates that frail people face adversities in a worse way in relation to their sexuality. 
Table 2. Details of the self-reported frailty instrument

\begin{tabular}{|c|c|c|c|}
\hline Components & Questions & $\mathbf{n}$ & $\%$ \\
\hline \multirow{4}{*}{ Weight loss } & In the past 12 months, have you lost weight without going on a diet? & & \\
\hline & No & 179 & 71.6 \\
\hline & Yes, between $1 \mathrm{~kg}$ and $3 \mathrm{~kg}$ & 36 & 14.4 \\
\hline & Yes, more than $3 \mathrm{~kg}$ & 35 & 14.0 \\
\hline \multirow{3}{*}{ Weakness } & $\begin{array}{l}\text { In the last } 12 \text { months (last year), do you feel weaker, do you think } \\
\text { your strength has decreased? }\end{array}$ & & \\
\hline & No & 122 & 48.8 \\
\hline & Yes & 128 & 51.2 \\
\hline \multirow{3}{*}{ Slowness } & $\begin{array}{l}\text { Do you think you are walking slower today than you walked } 12 \\
\text { months ago (one year ago)? }\end{array}$ & & \\
\hline & No & 132 & 52.8 \\
\hline & Yes & 118 & 47.2 \\
\hline \multirow{3}{*}{$\begin{array}{l}\text { Low physical } \\
\text { activity }\end{array}$} & $\begin{array}{l}\text { Do you think you do less physical activity than you did } 12 \text { months ago } \\
\text { (one year ago)? }\end{array}$ & & \\
\hline & No & 91 & 36.4 \\
\hline & Yes & 159 & 63.6 \\
\hline \multirow{10}{*}{ Exhaustion } & $\begin{array}{l}\text { How often, in the last week, did you feel that you couldn't get on with } \\
\text { your stuff (starting something but couldn't finish it)? }\end{array}$ & & \\
\hline & Never or rarely (less than 1 day) & 135 & 54.0 \\
\hline & Few times (1-2 days) & 72 & 28.8 \\
\hline & Sometimes (3-4 days) & 36 & 14.4 \\
\hline & Most of the time & 7 & 2.8 \\
\hline & $\begin{array}{l}\text { How often, in the last week, did the performance of your routine } \\
\text { activities require a great effort from you to happen? }\end{array}$ & & \\
\hline & Never or rarely (less than 1 day) & 108 & 43.2 \\
\hline & Few times (1-2 days) & 94 & 37.6 \\
\hline & Sometimes (3-4 days) & 39 & 15.6 \\
\hline & Most of the time & 9 & 3.6 \\
\hline
\end{tabular}

Source: self-elaboration based on Nunes et al. (12).

Furthermore, it is noteworthy that, in general, older adults experience their sexuality better in affective relationships when compared to the sexual act, although the observed scores are not so out of line. It is noteworthy that the IQ indicates the values observed in the dispersion of data for each dimension evaluated.

Table 3. Sexuality of older adults according to frailty

\begin{tabular}{|c|c|c|c|c|}
\hline \multicolumn{5}{|c|}{ Frailty } \\
\hline \multirow{2}{*}{ Dimensions of sexuality } & Non-frail & Pre-frail & Frail & General \\
\hline & Median (IQ) & Median (IQ) & Median (IQ) & Median (IQ) \\
\hline Sexual act & $76(67.50-79)$ & $76.50(67.25-81)$ & $73(62-80)$ & $74(64-80)$ \\
\hline Affective relationships & $77(69-81)$ & $76.50(68-81.75)$ & $75(63-81)$ & $75(67-81)$ \\
\hline Physical and social adversity & $6(5-8.50)$ & $6(5-8)$ & $7(5-9)$ & $7(5-9)$ \\
\hline
\end{tabular}

Source: self-elaboration. 
As shown in Table 4, it is noted that, in the field of sexuality, the worst male gender faces physical and social adversity $(M R=121.99$; $p=0.048$ ). Furthermore, there was a statistical association between marital status, which indicated that older adults with a steady partner experience the sexual act better $(M R=161.48 ; p<0.001)$ and affective relationships ( $M R=145.03 ; p=0.003$ ) with respect to married people.

Another relevant finding concerns the statistical association identified in the time of living with a partner, in which older adults who have lived for five years or less experience the sexual act better $(M R=167.64 ; p<0.001)$ and relationships affective $(M R=152.92$; $\mathrm{p}=0.009$ ) compared to those who have lived together for more than 20 years.

Entering the field of frailty, there is a prevalence of $98 \%(n=245)$ of older adults in the frailty process, with $33.6 \%(n=84)$ being classified as pre-frail and $64.4 \%(n=161)$ classified as frail. Among those in the frailty process, there was a higher prevalence of men $(64.4 \% ; n=161)$, aged between 60 and 64 years old $(40.8 \%, n=102)$ and who lived with their partner for more than 20 years $(63.6 \%, n=159)$. Other information is described in Table 4.

Table 4. Association between biosociodemographic data with sexuality and older adults frailty

\begin{tabular}{|c|c|c|c|c|c|c|}
\hline \multirow{3}{*}{ Variables } & \multicolumn{3}{|c|}{ Sexuality } & \multicolumn{3}{|c|}{ Frailty } \\
\hline & Sexual act & $\begin{array}{c}\text { Affective } \\
\text { relationships }\end{array}$ & $\begin{array}{l}\text { Physical } \\
\text { and social } \\
\text { adversity }\end{array}$ & $\begin{array}{c}\text { Non-frail } \\
(n=5)\end{array}$ & $\begin{array}{l}\text { Pre-frail } \\
(n=84)\end{array}$ & $\begin{array}{c}\text { Frail } \\
(n=161)\end{array}$ \\
\hline & \multicolumn{3}{|c|}{ Middle ranks } & \multicolumn{3}{|c|}{ Absolute and relative frequencies } \\
\hline \multicolumn{7}{|l|}{ Gender } \\
\hline Male & 121.52 & 120.91 & 121.99 & $5(100 \%)$ & $57(67.9 \%)$ & $104(64.6 \%)$ \\
\hline Female & 133.38 & 131.51 & 103.55 & $\mathrm{O}(0 \%)$ & $27(32.1 \%)$ & $57(35.4 \%)$ \\
\hline$P$ value & 0.220 & 0.270 & $0.048^{*}$ & - & - & - \\
\hline \multicolumn{7}{|l|}{ Age group } \\
\hline $60-64$ years old & 131.93 & 131.60 & 109.51 & $3(60 \%)$ & $34(40.5 \%)$ & $68(42.2 \%)$ \\
\hline $65-69$ years old & 125.24 & 122.09 & 119.45 & $1(20 \%)$ & $37(44.0 \%)$ & $61(37.9 \%)$ \\
\hline 70-74 years old & 122.59 & 116.56 & 126.02 & o (o \%) & $10(11.9 \%)$ & $25(15.5 \%)$ \\
\hline 75-79 years old & 83.05 & 113.50 & 118.06 & $1(20 \%)$ & $3(3.6 \%)$ & $6(3.7 \%)$ \\
\hline $80-84$ years old & 3.00 & 11.0 & - & ० (0 \%) & ० (0\%) & 1 (0.6\%) \\
\hline$P$ value & 0.125 & 0.366 & 0.584 & - & - & - \\
\hline \multicolumn{7}{|l|}{ Religion } \\
\hline Catholic & 119.15 & 120.49 & 117.35 & $3(60 \%)$ & $54(64.3 \%)$ & $93(57.8 \%)$ \\
\hline Protestant & 146.45 & 133.29 & 115.30 & $1(20 \%)$ & $9(10.7 \%)$ & $18(11.2 \%)$ \\
\hline Spiritualism & 139.22 & 140.32 & 122.02 & o (0 \%) & $6(7.1 \%)$ & $19(11.8 \%)$ \\
\hline African origins & 200.75 & 187.32 & 114.75 & ० (० \%) & $1(1.2 \%)$ & $3(1.9 \%)$ \\
\hline Others & 122.48 & 120.95 & 115.63 & $1(20 \%)$ & $7(8.3 \%)$ & $12(7.5 \%)$ \\
\hline No religion & 116.07 & 114.54 & 102.19 & ० (0 \%) & $7(8.3 \%)$ & $16(9.9 \%)$ \\
\hline$P$ value & 0.102 & 0.335 & 0.948 & - & - & - \\
\hline
\end{tabular}




\begin{tabular}{|c|c|c|c|c|c|c|}
\hline \multicolumn{7}{|l|}{ Ethnicity } \\
\hline White & 126.18 & 125.76 & 112.85 & $3(60 \%)$ & $62(73.8 \%)$ & $106(65.8 \%)$ \\
\hline Yellow & 108.00 & 92.80 & 171.70 & ० (0\%) & $1(1.2 \%)$ & $4(2.5 \%)$ \\
\hline Black & 91.79 & 86.38 & 136.50 & $1(20 \%)$ & $1(1.2 \%)$ & $10(6.2 \%)$ \\
\hline Brown & 132.66 & 131.89 & 117.47 & $1(20 \%)$ & $20(23.8 \%)$ & $37(23.0 \%)$ \\
\hline Indigenous & 115.75 & 121.13 & 150.75 & ० (0 \%) & ० (0\%) & $4(2.5 \%)$ \\
\hline$P$ value & 0.468 & 0.284 & 0.300 & - & - & - \\
\hline \multicolumn{7}{|l|}{ Education } \\
\hline Primary & 130.89 & 119.39 & 131.25 & o (0 \%) & $6(7.1 \%)$ & $17(10.6 \%)$ \\
\hline Elementary School I & 140.68 & 127.75 & 120.75 & $1(20 \%)$ & $6(7.1 \%)$ & $13(8.1 \%)$ \\
\hline Elementary School II & 110.03 & 110.60 & 105.15 & $4(80 \%)$ & $4(4.8 \%)$ & $11(6.8 \%)$ \\
\hline High school & 124.84 & 121.16 & 116.34 & o (0\%) & $28(33.3 \%)$ & $50(31.1 \%)$ \\
\hline Higher education & 125.24 & 129.85 & 113.00 & ० (0 \%) & $40(47.6 \%)$ & $69(42.9 \%)$ \\
\hline No education & 12.50 & 77.0 & - & o (0 \%) & ० (0 \%) & $1(0.6 \%)$ \\
\hline$P$ value & 0.528 & 0.858 & 0.769 & - & - & - \\
\hline \multicolumn{7}{|l|}{ Marital status } \\
\hline Married & $112.00^{\ddagger}$ & $113.63^{\ddagger, \S}$ & 120.12 & $3(60 \%)$ & $57(67.9 \%)$ & $107(66.5 \%)$ \\
\hline Stable union & 142.73 & $147.33^{\S}$ & 119.56 & $1(20 \%)$ & $12(14.3 \%)$ & $26(16.1 \%)$ \\
\hline With a partner & $161.48^{\ddagger}$ & $145.03^{\ddagger}$ & 98.93 & $1(20 \%)$ & $15(17.9 \%)$ & $28(17.4 \%)$ \\
\hline$P$ value & $<0.001^{\dagger}$ & $0.003^{\dagger}$ & 0.164 & - & - & - \\
\hline \multicolumn{7}{|c|}{ Time living with the partner } \\
\hline$\leq 5$ years & $167.64^{\ddagger}$ & $152.92^{\ddagger}$ & 102.49 & o (o \%) & $16(19.0 \%)$ & $21(13.0 \%)$ \\
\hline $\begin{array}{l}\text { Between } 6 \text { and } 10 \\
\text { years }\end{array}$ & $159 \cdot 48^{\S}$ & 154.48 & 119.70 & 1 (20 \%) & $4(4.8 \%)$ & $17(10.6 \%)$ \\
\hline $\begin{array}{l}\text { Between } 11 \text { and } 15 \\
\text { years }\end{array}$ & 118.46 & $107 \cdot 54$ & 116.15 & ० (० \%) & $3(3.6 \%)$ & $10(6.2 \%)$ \\
\hline $\begin{array}{l}\text { Between } 16 \text { and } 20 \\
\text { years }\end{array}$ & 148.72 & 133.19 & 131.53 & $1(20 \%)$ & $8(9.5 \%)$ & $7(4.3 \%)$ \\
\hline$>20$ years & $109.53^{\ddagger, \S}$ & $114.57^{\ddagger}$ & 117.15 & $3(60 \%)$ & $53(63.1 \%)$ & $106(65.8 \%)$ \\
\hline$P$ value & $<0.001^{\dagger}$ & $0.009^{\dagger}$ & 0.639 & - & - & - \\
\hline \multicolumn{7}{|c|}{ Living with their children } \\
\hline Yes & 122.61 & 116.43 & 119.77 & $1(20 \%)$ & $14(16.7 \%)$ & $46(28.6 \%)$ \\
\hline No & 122.94 & 123.78 & 115.09 & $4(80 \%)$ & $62(73.8 \%)$ & $108(67.1 \%)$ \\
\hline Do not have children & 167.00 & 165.53 & 111.03 & o (o \%) & $8(9.5 \%)$ & $7(4.3 \%)$ \\
\hline P value & 0.072 & 0.058 & 0.860 & - & - & - \\
\hline \multicolumn{7}{|c|}{ Have you ever had guidance on sexuality by health professionals? } \\
\hline Yes & 131.41 & 134.61 & 114.63 & $1(20 \%)$ & $21(25.0 \%)$ & $36(22.4 \%)$ \\
\hline No & 123.71 & 121.48 & 116.42 & $4(80 \%)$ & $63(75.0 \%)$ & $125(77.6 \%)$ \\
\hline$P$ value & 0.477 & 0.225 & 0.862 & - & - & - \\
\hline \multicolumn{7}{|l|}{ Sexual orientation } \\
\hline Heterosexual & 127.97 & 127.83 & 112.73 & $5(100 \%)$ & $77(91.7 \%)$ & $137(85.1 \%)$ \\
\hline Homosexual & 153.67 & 142.67 & 86.83 & ० (0\%) & $1(1.2 \%)$ & $2(1.2 \%)$ \\
\hline Bisexual & 120.00 & 94.75 & 114.63 & o (0\%) & O (0\%) & $4(2.5 \%)$ \\
\hline Others & 100.40 & 95.74 & 146.33 & o (o \%) & $6(7.1 \%)$ & $18(11.2 \%)$ \\
\hline Pvalue & 0.304 & 0.168 & 0.101 & - & - & - \\
\hline
\end{tabular}

*Statistical significance by Mann-Whitney test $(p<0.05)$.

+Statistical significance by the Kruskal-Wallis test $(p<0.05)$.

$\ddagger, \S$ Statistically significant difference by Bonferroni post-hoc.

Source: self-elaboration. 
It is observed in Table 5 that the correlations found between sexuality and frailty were positive and weakly negative, but with a statistical association. It is noteworthy that the positive correlations indicate that the two variables have a directly proportional behavior, while the negative ones, inversely proportional. Furthermore, cross-sectional studies do not allow the identification of causality.

It is observed that all dimensions of sexuality were statistically correlated with reduced strength, reduced walking speed and reported fatigue. Thus, it is noted that the greater the experience of the sexual act, the smaller the reduction in strength $(\rho=-0.263 ; p<0.001)$ and walking speed $(\rho=-0.201 ; p=0.001)$ will be and the greater will be the reported fatigue $(\rho=0.149 ; p=0.018)$.

Furthermore, the greater the experience of affective relationships, the smaller the reduction in strength $(\rho=-0.254 ; p<0.001)$ and walking speed $(\rho=-0.207 ; p=0.001)$ and the greater the reported fatigue $(\rho=0.207 ; p=0.001)$.

Finally, the more the older adults face physical and social adversities, the greater will be the reduction in strength $(p=0.279 ; p<$ 0.001 ), in walking speed ( $\rho=0.261 ; p<0.001$ ), in low physical activity $(\rho=0.140 ; p=0.034)$ and less fatigue will be reported $(\rho=-0.171$; $\mathrm{p}=0.009)$.

Table 5. Correlation between sexuality and frailty

\begin{tabular}{|c|c|c|c|}
\hline Sexuality & Frailty & Spearman's $\rho$ & P value \\
\hline \multirow{5}{*}{ Sexual act } & Weight loss & 0.072 & 0.259 \\
\hline & Weakness & -0.263 & $<0.001^{*}$ \\
\hline & Slowness & -0.201 & $0.001^{*}$ \\
\hline & Low physical activity & -0.109 & 0.084 \\
\hline & Exhaustion & 0.149 & $0.018^{*}$ \\
\hline \multirow{5}{*}{$\begin{array}{l}\text { Affective } \\
\text { relationships }\end{array}$} & Weight loss & 0.019 & 0.770 \\
\hline & Weakness & -0.254 & $<0.001^{*}$ \\
\hline & Slowness & -0.207 & $0.001^{*}$ \\
\hline & Low physical activity & -0.087 & 0.172 \\
\hline & Exhaustion & 0.207 & $0.001^{*}$ \\
\hline \multirow{5}{*}{$\begin{array}{c}\text { Physical and } \\
\text { social adversity }\end{array}$} & Weight loss & 0.023 & 0.733 \\
\hline & Weakness & 0.279 & $<0.001^{*}$ \\
\hline & Slowness & 0.261 & $<0.001^{*}$ \\
\hline & Low physical activity & 0.140 & $0.034^{*}$ \\
\hline & Exhaustion & -0.171 & $0.009^{*}$ \\
\hline
\end{tabular}

*Statistical significance $(p<0.05)$.

Source: self-elaboration. 


\section{Discussion}

In this study, a prevalence of $98 \%(n=245)$ of older adults in the frailty process was observed, a value higher than that found in similar studies that also used the same assessment instrument carried out in Tocantins (66.7 \%) (15), Rio Grande do Sul (80.5 \%) (16) and Sao Paulo (83.9 \%) (17), in addition to being superior even to that found in a study that used different approaches to measurement $(78.7 \%)(6)$. It is worth mentioning that the information regarding the prevalence and incidence of frailty in older adults is insufficient, which may reflect the lack of consensus on the criteria capable of constituting screening parameters in different populations (6).

Among older adults in the frailty process, there was a higher prevalence of men $(64.4 \% ; n=161)$, diverging from other studies (18-20), that found a higher prevalence in women. In fact, the female gender is considered a risk factor for frailty (21). Of the reasons that justify this evidence, the fact that women have a lower rate of lean mass and muscle strength, are more vulnerable to sarcopenia, and have a higher survival rate are mentioned, which consequently exposes them for longer to chronic diseases (6), to central and peripheral degenerations, in addition to the increase in adipose tissue and the reduction in the intensity of daily activities (21).

However, although in this study the highest prevalence of the frailty process was found in men, it does not eliminate the need for early interventions, especially in older adults classified as pre-frail, which corresponded to $67.9 \%$ of men $(n=57)$ and $32.1 \%$ of women $(n=27)$. Such interventions must be carried out in order to prevent or delay as much as possible the onset of frailty and, consequently, functional incapacity (21).

Those classified as frail had the worst experiences in all dimensions of sexuality, in which the lowest medians indicated that they had the worst experience in the sexual act and in affective relationships and the highest median indicated worse coping with physical and social adversities, when compared with the non-frail and pre-frail older adults.

The sexual act dimension refers, in fact, to the sexual practice between spouses and how older adults perceive and enjoy it. The "affective relationships" dimension involves aspects such as affection, love, complicity, companionship, affection, friendship, trust, pleasure, support and other qualitative feelings. Finally, the dimension "physical and social adversity" refers to health problems that interfere in the experiences of sexuality, for fear of being victims of prejudice due to the attitudes taken to experience it and how older adults behave in the face of the changes that have occurred in sexuality due to the aging process (11).

Furthermore, it is noteworthy that, in general, older adults experience their sexuality better in affective relationships when compared 
to the sexual act, although the scores observed in this study were not so out of line. It is mentioned that these results are in accordance with a study (22) developed with a total of 213 English, Brazilian and Portuguese older adults, which identified some more prevalent expressions of sexuality among the participants, such as affection, attention, altruism, eroticism, positive communication and attractiveness, with the sexual component not being considered an immediate priority (22), although it is also one of the ways of expressing sexuality.

Another investigation (23) carried out with a total of 100 women older adults showed that, among the ways of expressing sexuality, the participants reported the involvement of autoeroticism, kisses and cuddles. It is noteworthy that sexuality goes beyond the limits of sexual practice and encompasses several other qualitative manifestations that provide pleasure and well-being (23). Nevertheless, the fact is that, in old age, the sexual act seems to assume a secondary position, while other manifestations such as care, affection and emotions assume a prominent position in the sexuality of older adults (24).

In this study, one of the dimensions of sexuality is the physical and social adversity, in which it was found that, for having a higher middle rank, the male gender is worse faced with the adversities that often reflect on the sense of masculinity and its social construction. Currently, men who are unable to become sexually involved feel "less like a man", which demonstrates the power of sexual capacity for the social construction of masculinity (25). This sexual incapacity is strictly related to dysfunctions, especially those related to penile erection, as, physiologically, erectile dysfunctions are more frequent in older ages and affect not only the sexual act itself, but also the entire context of masculinity and well-being of these individuals (26). Thus, men with erection problems frequently experience psychosexual stressors, loss of self-confidence and marital conflicts, which end up enhancing the aforementioned dysfunction (27).

Sexual ability is so strongly linked to a sense of masculinity that, since adolescence, men are encouraged to initiate and learn sexual practices whenever desired. On the other hand, women were always limited with regard to sexual freedom before marriage, and their virginity should be preserved until the day the marriage was signed (24). Therefore, when men reach old age and perceive themselves without their sexual capacity, internal conflicts occur that can explain at least one issue corresponding to the dimension of adversity: the discomfort caused by changes in sexuality due to the aging process (erectile dysfunction).

Another important finding in this study concerns the statistical association between marital status, which indicates that older adults with a steady partner experience sexual intercourse better than married people. This is a curious finding, as it is inferred that older adults with a steady partner are those who, for some reason (di- 
vorce, widowhood, among others) have sought new partners to maintain not only sexual relationships, but loving ones. However, it was expected that this better experience in the sexual act would be observed in married people, as marriage is seen as a space for healthy exchange of affective and sexual expressions that contribute to strengthening the dynamics between spouses (28).

Somehow, this fact can represent some degree of self-indulgence that occurs among older adults within marriage, especially due to the routine and monotony that occur over the years of conjugality, which generate negative impacts on the conception and in the expression of sexuality (29). Furthermore, this context may also explain why older adults who have lived with their partners for five years or less experience sexual intercourse and affective relationships better than those who have lived together for more than 20 years, as found in this study.

It was observed that all dimensions of sexuality were statistically correlated with reduced strength, reduced walking speed and reported fatigue. Only the dimension "physical and social adversity" correlated with an additional component of frailty - low physical activity.

Only data referring to male sexual dysfunction and its relationship with frailty were found in the literature. As an example, a European study carried out with a total of 1504 men older adults between 60 and 79 years old revealed that frailty was associated with an increase in the chances of erectile dysfunction. Furthermore, frailty was associated with impaired general sexual functioning, suffering related to sexual function and erectile dysfunction (30). Another Chinese community-based study conducted with 341 men older adults aged 60 to 83 years old revealed a strong association between erectile dysfunction and frailty among the participants, evidencing the need to consider erectile dysfunction in multidimensional assessments of frailty (31).

Attention is drawn to the lack of studies that compare the influence of sexuality on frailty among older adults. The few existing research focus on male sexual dysfunction without considering sexuality as an integral component of the individual's identity. Furthermore, it is worth mentioning that not even female sexual dysfunctions are addressed in the few studies found. Thus, the discussion of results with the national and international literature was impaired, but the relevant point that deserves to be highlighted is that all this limitation makes our data unprecedented and pioneering in the subject. Therefore, we encourage further research that aims to provide data capable of demonstrating the influence of sexuality on the frailty of older adults, especially longitudinal studies, to enable the causal relationship.

\section{Conclusion}

This study revealed a high prevalence of older adults in the frailty process. Thy experienced their sexuality better in affective rela- 
tionships and those classified as frail had the worst experiences in sexuality. Furthermore, all dimensions of sexuality were statistically correlated with decreased strength, decreased walking speed and reported fatigue. Only the dimension "physical and social adversity" was correlated with an additional component of frailty - low physical activity. It is noteworthy that the correlations found were positive and negative, both with weak magnitude.

It is noteworthy that this study has some limitations. Initially, the impossibility of generalizing the results is mentioned, due to both the non-probabilistic sampling and the sampling restriction of only older adults with internet access and an active account only on the Facebook social network. This is a population specificity that does not represent the reality of most of them, as the participants in this study had a high level of education and, consequently, better reading and text comprehension skills, in addition to the socioeconomic benefits that education can provide. Therefore, caution is required when interpreting and comparing our results, especially with investigations carried out whose participants do not resemble the sociodemographic profile of this study.

Conflict of interest: none declared.

\section{References}

1. Ventriglio A, Bhugra D. Sexuality in the 21st Century: Sexual Fluidity. East Asian Arch Psychiatry. 2019;29(1):30-4. DOI: https:// doi.org/10.12809/eaap1736

2. Srinivasan S, Glover J, Tampi RR, Tampi DJ, Sewell DD. Sexuality and the older adult. Curr Psychiatry Rep. 2019;21:97. DOI: https://doi.org/10.1007/s11920-019-1090-4

3. Whittle C, Butler C. Sexuality in the lives of people with intellectual disabilities: A meta-ethnographic synthesis of qualitative studies. Res Dev Disabil. 2018;75:68-81. DOI: https://doi. org/10.1016/j.ridd.2018.02.008

4. He W, Goodkind D, Kowal P. An aging world: 2015. International population reports, P95/16-1 Bureau USC (Ed.), U.S. Government Publishing Office, Washington, DC [internet]; 2016. Available from: https://www.census.gov/content/dam/Census/ library/publications/2016/demo/p95-16-1.pdf

5. Walston J, Buta B, Xue QL. Frailty screening and interventions: Considerations for clinical practice. Clin Geriatr Med. 2018;34(1):25-38. DOI: https://doi.org/10.1016/j.cger.2017.09.004

6. Santos PHS, Fernandes MH, Casotti CA, Coqueiro RS, Carneiro JAO. Perfil de fragilidade e fatores associados em idosos cadastrados em uma Unidade de Saúde da Família. Ciênc saúde coletiva. 2015;20(6):1917-24. DOI: https://doi.org/10.159o/141381232015206.17232014

7. Fried LP, Tangen CM, Walston J, Newman AB, Hirsch C, Gottdiener $)$ et al. Frailty in older adults: Evidence for a phenotype. J Gerontol A Bio Sci Med Sci. 2001;56(3):146-56. DOI: https://doi. org/10.1093/gerona/56.3.M146

8. Coelho T, Paúl C, Gobbens RJJ, Fernandes L. Multidimensional Frailty and Pain in Community Dwelling Elderly. Pain Med. 2016;18(4):693-701. DOI: https://doi.org/10.1111/pme.12746
9. Antonovsky A. The salutogenic model as a theory to guide health promotion. Health Promot Int. 1996;11(1):11-8. DOI: https://doi.org/10.1093/heapro/11.1.11

10. Esquivel Garzón N, Díaz Heredia LP. Salutogenesis and cardiovascular health in adults: A scoping review. Texto contexto-enferm. 2020;29:e20180376. DOI: https://doi.org/10.159o/1980265x-tce-2018-0376

11. Vieira KFL. Sexualidade e qualidade de vida do idoso: desafios contemporâneos e repercussões psicossociais [internet]. João Pessoa: Universidade Federal da Paraíba; 2012. Disponível em: https://repositorio.ufpb.br/jspui/bitstream/tede/6908/1/arquivototal.pdf

12. Nunes DP, Duarte YAO, Santos JLF, Lebrão ML. Screening for frailty in older adults using a self-reported instrument. Rev Saúde Pública. 2015;49(1). DOI: https://doi.org/10.159o/So0348910.2015049005516

13. Freitas FFQ, Soares SM. Clinical-functional vulnerability index and the dimensions of functionality in the elderly person. Rev Rene. 2019;20:e39746. DOI: https://doi.org/10.15253/21756783.20192039746

14. Hulley SB, Cumming SR, Browner WS, Grady DG, Hearst NB, Newman TB. Delineando a pesquisa clínica: uma abordagem epidemiológica. $2^{\text {a }}$ ed. Porto Alegre: Artmed; 2003.

15. Cavalcanti Júnior EO, Araújo EQX, Evangelista DR, Rezende FAC, Silva Netto LS, Osório NB et al. Relação das condições de vida e saúde sobre a fragilidade em idosos. Rev Humanid Inov [internet]. 2019;6(11):76-87. Disponível em: https://revista.unitins.br/ index.php/humanidadeseinovacao/article/view/1574

16. Pereira De Llano PM, Lange $C$, Nunes DP, Pastore CA, Pinto $\mathrm{AH}, \mathrm{Casagranda}$ LP. Frailty in rural older adults: Development 
of a care algorithm. Acta Paul Enferm. 2017;30(5):520-50. DOI: https://doi.org/10.1590/1982-0194201700075

17. Moura K, Jesus ITM, Orlandi AAS, Zazzetta MS. Fragilidade e suporte social de idosos em região vulnerável: uma abordagem em uma unidade de saúde da família. Revista deAtenção à Saúde. 2020;18(63):65-73. DOI: https://doi.org/10.13037/ras. vol18n63.6342

18. Gross CB, Kolankiewicz ACB, Schmidt CR, Berlezi EM. Frailty levels of elderly people and their association with sociodemographic characteristics. Acta Paul Enferm. 2018;31(2):209-16. DOI: https://doi.org/10.1590/1982-0194201800030

19. Farías-Antúnez S, Fassa AG. Frailty prevalence and associated factors in the elderly in Southern Brazil, 2014. Epidemiol Serv Saúde. 2019;28(1):e2017405. DOI: https://doi.org/10.5123/S167949742019000100008

20. Preto LSR, Conceição MCD, Amaral SIS, Figueiredo TM, Preto PMB. Frailty and associated risk factors in independent older people living in rural areas. Revista de Enfermagrm Referência. 2018;(16):73-84. DOI: https://doi.org/10.12707/RIV17078

21. Berlezi EM, Gross CB, Pimentel JJ, Pagno AR, Fortes CK, Pillatt AP. Estudo do fenótipo de fragilidade em idosos residentes na comunidade. Ciênc saúde colet. 2019;24(11):4201-10. DOI: https://doi.org/10.1590/1413-812320182411.31072017

22. Humboldt VS, Ribeiro-Gonçalves J, Costa A, Leal I. How do older adults express themselves sexually? An exploratory study. Psicol saúde doenças. 2020;21(01):62-8. DOI: https://doi. org/10.15309/20psd210110

23. Rodrigues LR, Portilho P, Tieppo A, Chambo Filho A. Analysis of the sexual behavior of elderly women treated at a gynecological outpatient clinic. Rev bras geriatr gerontol. 2018;21(6):724-30. DOI: https://doi.org/10.159o/1981-22562018021.18009o
24. Barros TAF, Assunção ALA, Kabengele DC Sexualidade na terceira idade: sentimentos vivenciados e aspectos influenciadores [internet]. 2020;6(1):47-62. Disponível em: https://periodicos. set.edu.br/fitsbiosaude/article/download/656o/3888\#: :tex$\mathrm{t}=\mathrm{Em} \% 20 \mathrm{se} \% 2$ otratando\%20de\%2oterceira,de\%20vida\%20 para\% $200 \% 20$ idoso

25. Martins ERC, Alves FS, Oliveira KL, Medeiros AS, Fassarella LG. Perception of man on the implantation of penile prosthesis: $A$ contribution to nursing. Braz J Hea Rev. 2020;3(3):6480-7. DOI: https://doi.org/10.34119/bjhrv3n3-196

26. Quijada PDS, Fernandes PA, Ramos SB, Santos BMO. Qualidade de vida relacionada à saúde de pacientes com câncer de próstata. Rev Cuid. 2017;8(3):1826-38. DOI: https://doi.org/10.15649/ cuidarte.v8i3.436

27. Chung E. Sexuality in Ageing Male: Review of Pathophysiology and Treatment Strategies for Various Male Sexual Dysfunctions. Med Sci. 2019;7(10):98. DOI: https://doi.org/10.339o/medsci7100098

28. Silva LA, Scorsolini-Comin F, Santos MA. Casamentos de longa duração: Recursos pessoais como estratégias de manutenção do laço conjugal. Psico-USF. 2017;22(2):323-35. DOI: https://doi. org/10.1590/1413-82712017220211

29. Almeida T, Lourenço ML. Envelhecimento, amor e sexualidade: utopia ou realidade? Rev bras geriatr gerontol. 2007;10(1):101-14. DOI: https://doi.org/10.1590/1809-9823.2007.10018

30. Lee DM, Tajar A, Ravindrarajah R, Pye SR, O'Connor DB, Corona $G$ et al. Frailty and sexual health in older European men. ) Gerontol A Bio Sci Med Sci.. 2013;68(7):837-44. DOI:https://doi. org/10.1093/gerona/gls217

31. Li C, Sun J, Zhao H, Dai T. Association between frailty and erectile dysfunction among chinese elderly men. Biomed Res Int. 2020. DOI: https://doi.org/10.1155/2020/9247237 